\title{
Road Mortality of Reptiles and Other Wildlife at the Ojibway Prairie Complex and Greater Park Ecosystem in Southern Ontario
}

\author{
Jonathan D. Choquette ${ }^{1,3}$ and Lindsey VALliant ${ }^{2}$ \\ ${ }^{1}$ SCC Ecological, P.O. Box 221 Station A, Windsor, Ontario N9A 6K1 Canada \\ ${ }^{2}$ Wildlife Preservation Canada, Guelph, Ontario N1H 6J2 Canada \\ ${ }^{3}$ Corresponding author: jchoquet@alumni.uoguelph.ca
}

Choquette, Jonathan D., and Lindsey Valliant. 2016. Road mortality of reptiles and other wildlife at the Ojibway Prairie Complex and Greater Park Ecosystem in southern Ontario. Canadian Field-Naturalist 130(1): 64-75.

The Ojibway Prairie Complex in Windsor contains the largest protected tallgrass prairie ecosystem in Ontario and supports numerous species at risk. Despite its ecological significance, it is crossed by multiple high-traffic roads. Road mortality is a major threat to endangered species in Canada, particularly reptiles. The main goal of this study was to describe the nature and extent of vertebrate road mortality, with a focus on reptiles, on roads bisecting the Ojibway Prairie Complex, and the Greater Park Ecosystem, in Windsor and LaSalle, Ontario. A systematic road mortality survey was conducted by bicycle along seven roads $(12.5 \mathrm{~km})$ in 2010,2012 , and 2013. Also, opportunistic observations $(n=103)$ spanning over 30 years were assembled from a variety of sources. In total, 2083 vertebrates (49 species), including 446 reptiles (11 species), were recorded "dead on road" during systematic surveys. The highest diversity of reptiles was recorded on Matchette Road, whereas the highest rate of reptile mortality was recorded on Malden Road. Reptile species at risk were killed on all roads surveyed. Combining systematic and opportunistic data, we found seven reptile species at risk: Butler's Gartersnake (Thamnophis butleri), Eastern Foxsnake (Pantherophis vulpinus), Eastern Massasauga (Sistrurus catenatus catenatus), Blanding's Turtle (Emydoidea blandingii), Eastern Musk Turtle (Sternotherus odoratus), Northern Map Turtle (Graptemys geographica), and Snapping Turtle (Chelydra serpentina). Reptile road mortality "hotspots" occurred where each road is intersected by a naturalized utility right-of-way. Our results can be used to focus mitigation efforts in space and time to reduce mortality rates and enhance connectivity in the Ojibway Prairie Complex and Greater Park Ecosystem.

Key Words: Reptiles; vertebrates; species at risk; road mortality; Ojibway Prairie Complex; Windsor; LaSalle; utility rightof-way

\section{Introduction}

Our understanding of the negative impacts of roads on wildlife is increasing. In Canada, road mortality is now considered a major threat to the persistence of endangered species, particularly reptiles (e.g., Row et al. 2007). Road mortality surveys have been used in areas of ecological importance to identify the nature and extent of wildlife road mortality (Ashley and Robinson 1996; Vijayakumar et al. 2001; Smith and Dodd 2003; Langen et al. 2007; Coelho et al. 2008; Shepard et al. 2008), and to measure the effectiveness of mitigation measures (Dodd et al. 2004; Aresco 2005; BaxterGilbert et al. 2015).

The Ojibway Prairie Complex (OPC), in extreme southwestern Ontario, is recognized as a Carolinian Canada Signature Site (Johnson 2005); it contains the largest protected tallgrass prairie remnant in Ontario, (Rodger 1998). This "complex" of tallgrass prairies, savannahs, forests, and provincially significant wetlands supports a multitude of regionally, provincially, and globally significant species of flora and fauna, some of which are found nowhere else in Canada (City of Windsor 2013). Furthermore, as many as 10 reptile species listed federally as at risk have been recently documented in the OPC and the surrounding greater park ecosystem (City of Windsor 2013; COSEWIC 2015).

Situated within an urban landscape, the OPC and Greater Park Ecosytem is surrounded and fragmented by residential, industrial, commercial, and agricultural lands as well as an extensive network of local, collector and arterial roads, in addition to a newly built provincial highway. Many species of wildlife, including at-risk reptiles, have been observed killed on these roads over the previous three decades (P. Pratt, unpublished data). These data were collected opportunistically, and no attempt has been made to document road mortality in this region systematically.

The main goal of this study was to describe the nature and extent of vertebrate road mortality, with a focus on reptiles and species at risk, on roads bisecting the OPC and Greater Park Ecosystem in the city of Windsor and the town of LaSalle. Our objectives were to identify which vertebrate species are killed on roads, estimate road mortality rates for each group, and identify spatial and temporal patterns of vertebrate road mortality.

\section{Methods}

\section{Systematic Road Mortality Surveys}

Seven collector and arterial roads in the study landscape were surveyed (Figure 1; Table 1). They were divided into two groups, reflecting different survey effort: in section B, all amphibians, birds, mammals, snakes, and turtles found dead on a road were recorded systematically, whereas, in section A, only dead snakes and turtles were recorded systematically. Also, more surveys were conducted in section $\mathrm{B}(n=157)$ than in

A contribution towards the cost of this publication has been provided by the Thomas Manning Memorial Fund of the Ottawa Field-Naturalist's Club. 


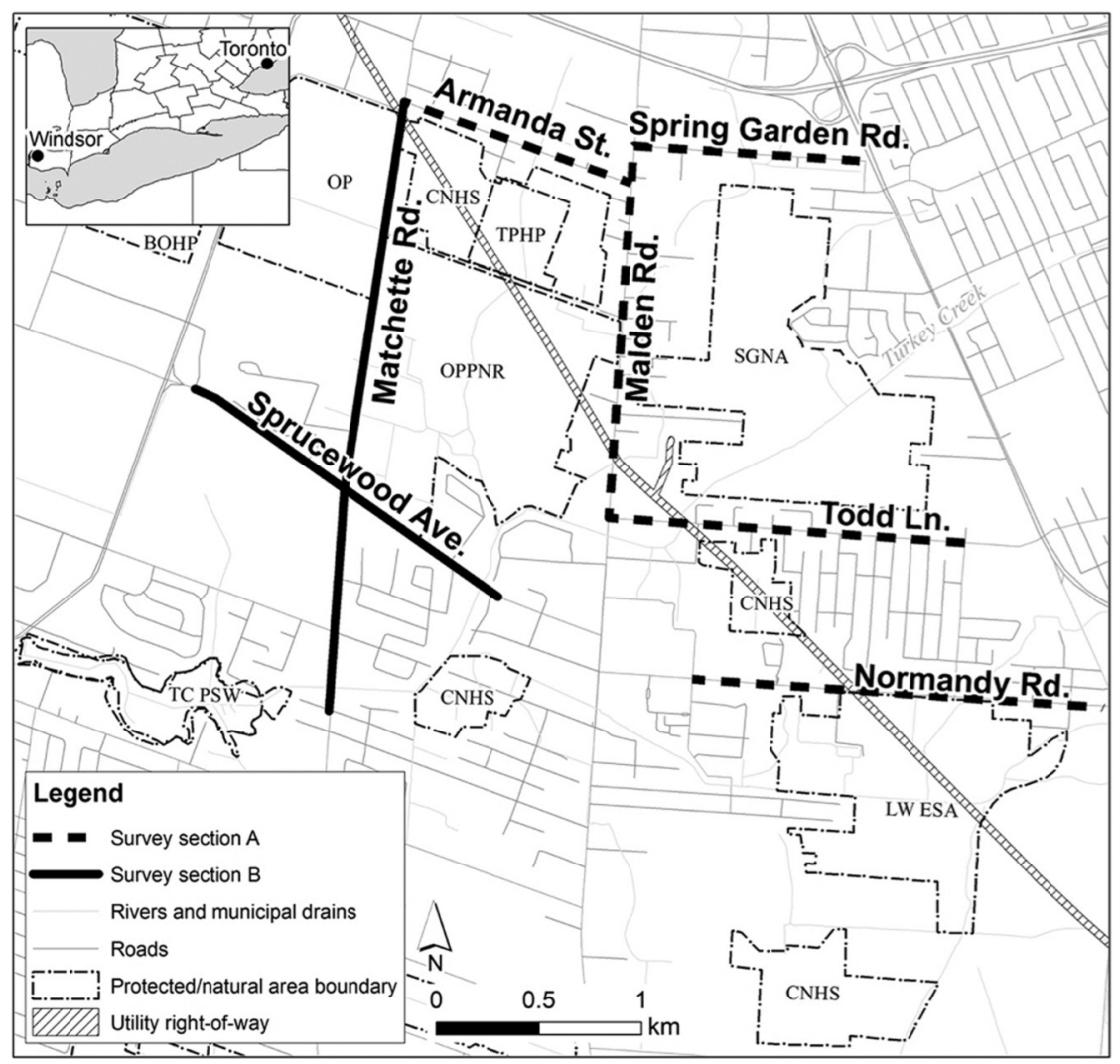

Figure 1. Map of the Ojibway Prairie Complex and Greater Park Ecosystem study area showing approximate boundaries of protected areas and roads surveyed for dead vertebrates during 2010-2013. BOHP = Black Oak Heritage Park, CNHS = Candidate Natural Heritage Site, LW ESA = LaSalle Woods Environmentally Significant Area, OP = Ojibway Park, OPPNR = Ojibway Prairie Provincial Nature Reserve, SGNA= Spring Garden Natural Area, TC PSW = Turkey Creek Provincially Significant Wetland, and TPHP = Tallgrass Prairie Heritage Park.

TABLE 1. Length, traffic intensity, and adjacent land use for roads surveyed during a systematic road mortality study in the Ojibway Prairie Complex and Greater Park Ecosystem in Windsor and LaSalle, Ontario, from 2010 to 2013.

\begin{tabular}{llll}
\hline \hline $\begin{array}{l}\text { Length of } \\
\text { survey route }(\mathrm{km})\end{array}$ & $\begin{array}{l}\text { Road } \\
\text { (length surveyed, } \mathrm{km})\end{array}$ & $\begin{array}{l}\text { Estimated average } \\
\text { annual daily traffic* }\end{array}$ & $\begin{array}{l}\text { Adjacent } \\
\text { land use } \dagger\end{array}$ \\
\hline Section A (7.85) & Armanda Street $(1.17)$ & $2200(2006$ data $)$ & $91 \%$ res, 9\% row \\
& Spring Garden Road $(1.09)$ & $2500(2005$ data) & $81 \%$ res, 8\% ins, 8\% row, 3\% com \\
& Malden Road (1.82) & $8654(2006$ data) & $67 \%$ res, 19\% row, 6\% com, 6\% nat, 2\% ins \\
& & $8000(2013$ data) & \\
& Todd Lane (1.74) & $9580-12027(2006$ data) & $85 \%$ res, 11\% row, 4\% rec \\
& Normandy Road (2.03) & $6619-8744(2006$ data) & $70 \%$ res, 18\% nat, 6\% rec, 4\% row, 2\% ins \\
Section B (4.75) & Matchette Road (3.00) & $6836-9300(2006$ data) & $54 \%$ res, 38\% nat, 6\% row, 2\% rec \\
& Sprucewood Avenue (1.75) & $4619-6235(2006$ data) & $58 \%$ res, 25\% rec, 12\% nat, 5\% row \\
& & $5700-9402(2008$ data) & \\
\hline
\end{tabular}

*Sources: Dillon Consulting (2007, 2009); P. Bouliane, personal communication, 2014; County of Essex (2014).

$\dagger$ Sources: City of Windsor (2007); Town of LaSalle (2014). "Adjacent land use" is estimated using a GIS by dividing the length of road frontage for a given land use or zoning designation (both sides of the road) by the total length of road frontage (i.e., double the road length). Note: $\mathrm{com}=$ commercial, ins $=$ institutional, nat $=$ natural heritage/environment, rec $=$ recreational, res $=$ residential, row $=$ opened and unopened road right-of-way. 
section A $(n=135)$. Results for snakes and turtles from both sections were pooled.

Roads were surveyed by bicycle at speeds of 12-17 $\mathrm{km} / \mathrm{h}$ on 3 days a week (on average every other day, except section A was surveyed on average every 4 days in 2010) for 52 non-consecutive weeks. Three technicians conducted road surveys: surveyor 1 in 2010-2013, surveyor 2 in 2012, and surveyor 3 in 2013. Surveys took place from May to mid-August in 2010 and 2013 and from late-August to October in 2012 and 2013. (Data from a single late-April survey are combined with May data.) The posted speed limit on all roads surveyed was $50 \mathrm{~km} / \mathrm{h}$. The survey route was traveled in a loop such that both lanes of each road were surveyed and it took about $3 \mathrm{~h}$ to complete a full survey. Surveys were always conducted with the flow of traffic; however, for each survey we alternated between completing section A or section B first. Most surveys (> 70\%) were completed between 1100 and 1700 . When all effort is combined, we surveyed the equivalent of almost $1800 \mathrm{~km}$ of roads, an average of $300 \mathrm{~km} /$ month (range 244-382 $\mathrm{km} /$ month).

For each specimen found dead on a road, the following data were recorded: UTM coordinates (accuracy of 5-10 m), road name, and location on road (yellow line, centre of lane, white line, or shoulder). During periods of high amphibian mortality, UTM coordinates were not recorded for these species; rather, these were tabulated by pre-defined road segment. Species, age class, and sex were also recorded when possible; however, many amphibians $(54 \%)$, birds (46\%), and mammals $(31 \%)$ could not be identified to species. Photographs were taken of all species listed as at risk by the Committee on the Status of Endangered Wildlife in Canada (COSEWIC 2015).

To avoid duplication of records, all dead specimens were removed from the road and discarded in adjacent vegetation or roadside swale. When physical removal was not possible (because of carcass condition or safety concerns), specimens were left in situ and the white line adjacent to the carcass was marked with a waterresistant cattle marker or lumber crayon. These marks continued to be visible for at least a week after marking, which was generally sufficient to allow for the specimen to be removed from the road by other means. Carcass persistence rates were not estimated. All animals encountered alive on roads were noted and either left in situ (if on the road shoulder) or helped across the road in the direction in which they appeared to be traveling.

\section{Opportunistic Data Collection}

Observations of snakes and turtles on roads, dead or alive, were also solicited from various local naturalists (including the authors) and organizations to assemble a dataset of opportunistic records. Opportunistic data were kept separate from those collected during our surveys. Observations in this dataset spanned over 30 years (1984-2014) and included records of snakes and turtles found dead $(n=106)$ and alive $(n=17)$ on roads in the study landscape. Many observations were provided by staff at the Ojibway Nature Centre. In most cases, records were verified by qualified personnel. All results reported here are based on our systematic data, unless otherwise specified.

\section{Data Analysis and Mapping}

Mortality rates are reported either as number of dead on road (DOR) individuals per $100 \mathrm{~km}$ surveyed (e.g., [446 DOR $/ 1798 \mathrm{~km}$ surveyed] $\times 100=24.8 \mathrm{DOR} /$ $100 \mathrm{~km}$ surveyed) or as number of DOR individuals per km per survey (e.g., [446 DOR] / [11.5 km per survey, on average $] /[157$ surveys $]=0.25 \mathrm{DOR} / \mathrm{km} / \mathrm{sur}-$ vey). Rates per month or per survey road were calculated in the same way, but using only the relevant subset of the data. Frequency estimates (DOR/km/survey) are assumed to be representative of daily mortality rates (i.e., DOR/ km/day) for birds, mammals, snakes, and amphibians, as other research has shown that most carcasses of these animals remain on the road for only one day (Enge and Wood 2002; DeGregorio et al. 2011; Santos et al. 2011). For turtles, however, per survey rates may not be synonymous with daily rates as some investigators have found most specimens remain on the road for two or more days (Langen et al. 2007; Santos et al. 2011).

To determine whether there were significant differences in the numbers of dead animals recorded per taxon across calendar months (data pooled by month, regardless of year), we made comparisons using a $\chi^{2}$ goodness-of-fit test using SPSS 22.0 (IBM, Armonk, New York, USA). Departures from expected equal frequencies across all months were determined by residuals that were greater or less than the critical value of \pm 1.96 . When a significant difference from an expected frequency was found, pairwise goodness-of-fit tests were performed to determine which months were significantly different from the others. Sample sizes were too low to compare monthly mortality rates for at-risk turtles.

Scientific names of all reptiles and amphibians follow Crother (2012). Maps were produced in ArcGIS version 9.1 (ESRI, Redlands, California, USA). All distances were determined using the "Measure" tool in ArcGIS.

\section{Spatial Analysis}

The distribution of reptile road mortality events was analyzed using Siriema version 1.1 (Coelho et al. 2006). Roadkill data were weighted for species at risk (SAR) using the following scheme based on the COSEWIC (2015) list: non-SAR/not at risk $=1$, special concern $=2$, threatened $=3$, endangered $=4$ (Table 2$)$; thus, "hotspots" (and any future mitigation efforts) would be biased toward such species. (A sensitivity analysis on Malden Road demonstrated that the location 

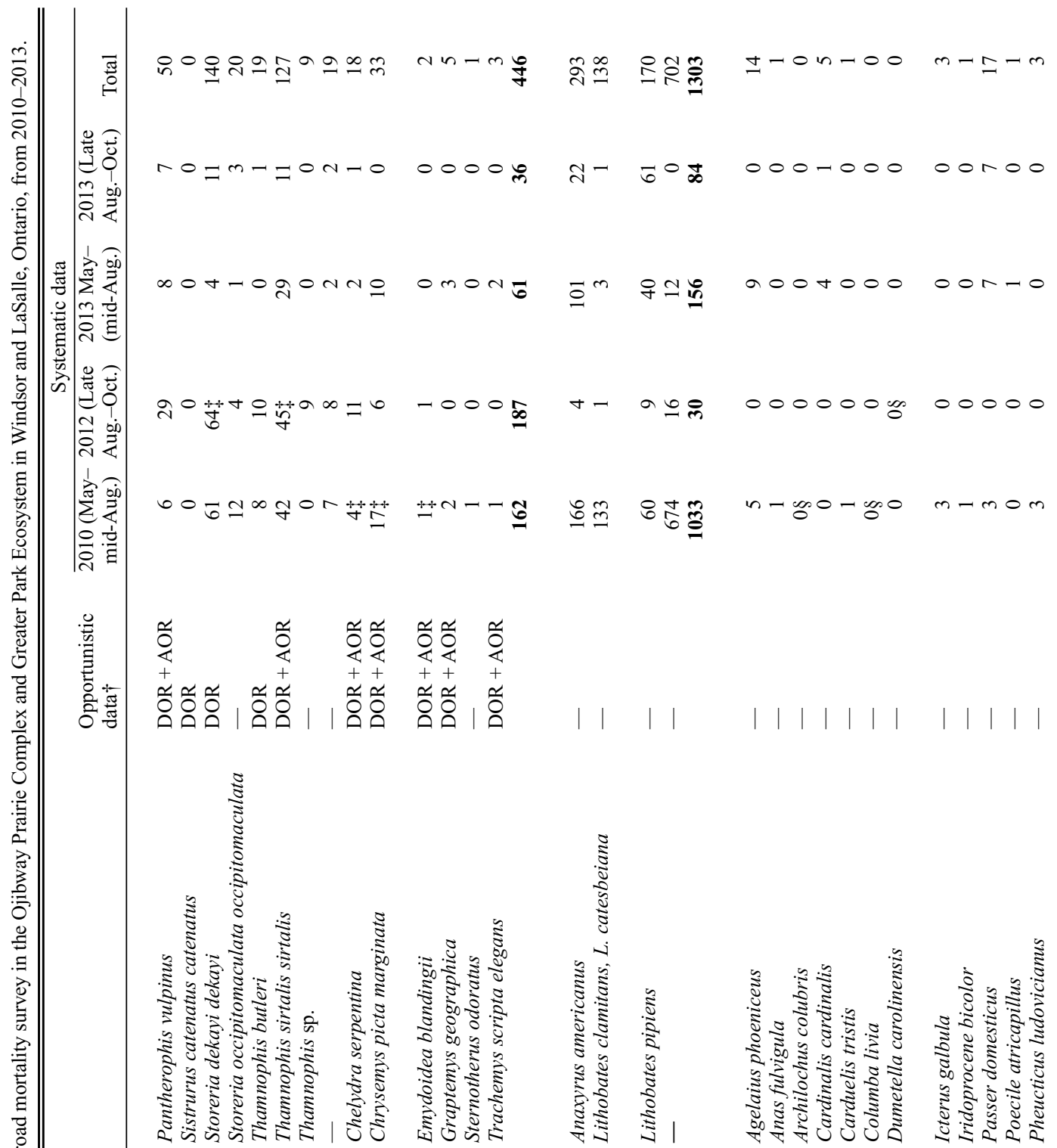<smiles>C1[C@H]2C[C@@H]12</smiles>

敢

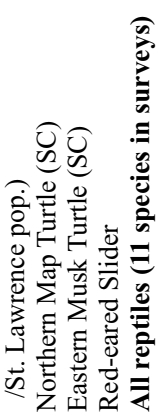

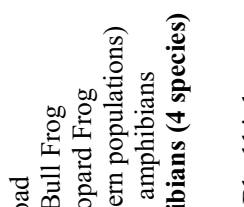

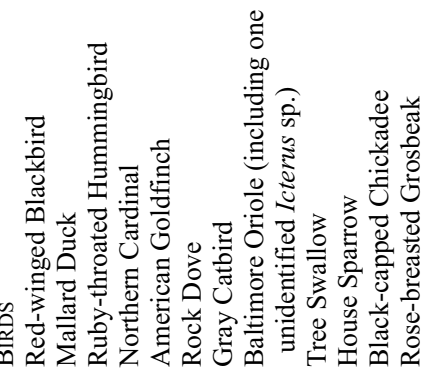




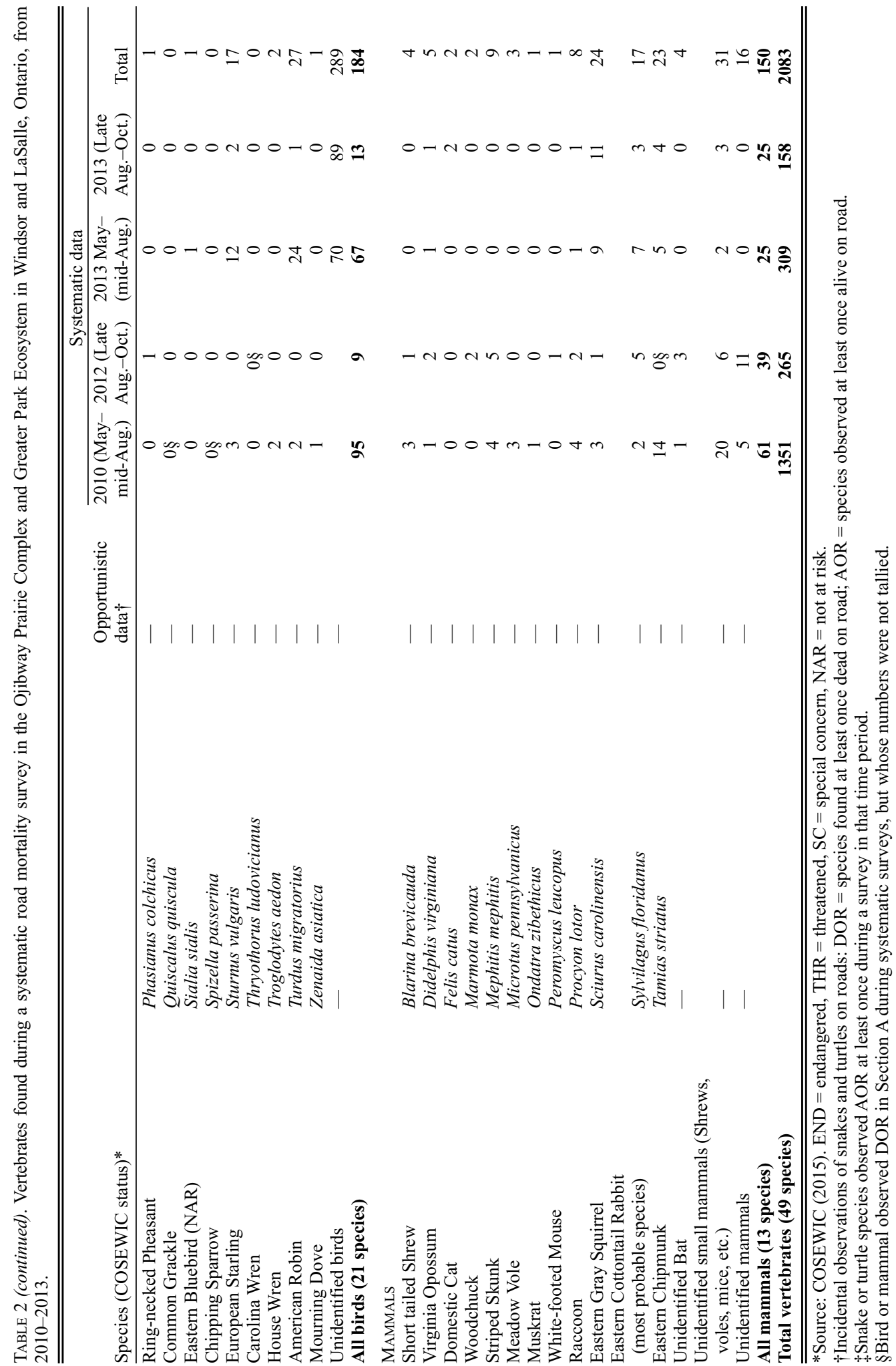


of mortality hotspots was sensitive to the SAR weighting.)

The Siriema analysis consisted of two steps (Coelho et al. 2008). First, Ripley's $K$ function is used to test for significant spatial aggregations of road mortality events $(L(r)$ values) on each study road, and, if found, to determine at which spatial scales (i.e., radius length) such aggregations occur. Second, using a relevant radius length from step one as an input, hotspot analysis is used to identify the relative locations along each road where significant spatial aggregations occur $\left(N_{\text {events }}{ }^{-}\right.$ $\left.N_{\text {simulated }}\right)$. We used a linear, as opposed to a twodimensional, $K$-function and hotspot analysis (Coelho et al. 2006) because all roads are linear (except for a minor curve on two of the roads), and no major differences were detected during an initial analysis of a sample of roads using both methods.

For the Ripley's $K$-function analysis, we used a $95 \%$ confidence interval (CI), an initial radius of $0.025 \mathrm{~km}$, a radius step of $0.025 \mathrm{~km}$, and 100 simulations. For the hotspot identification, we used a 95\% CI, 100 simulations, 500 road divisions, and two radii for each road: a radius for which the greatest intensity of spatial clustering was reported (from Ripley's $K$ ) and a radius of $0.050 \mathrm{~km}$. Two radii identified as having significant aggregations were used (one relatively longer than the other), so that results could better inform placement of both fine-scale (e.g., ecopassages) and broad-scale (e.g., barrier fencing or traffic calming) mitigation strategies (Coelho et al. 2006). Only roads with significant spatial aggregations of road mortality (based on Ripley's $K$ analysis) were subjected to hotspot identification. For north-south roads, kilometre 0.00 was set at the southern end and for east-west roads, kilometre 0.00 was set at the western end.

\section{Results}

Species Composition of Road Mortality

Overall, 2083 vertebrates of 49 species were found dead during systematic surveys. This includes four species of amphibians, 21 species of birds, 13 species of mammals, five species of snakes, and six species of turtles (Table 2). Eastern Gartersnakes (Thamnophis sirtalis sirtalis) and Northern Brownsnakes (Storeria dekayi dekayi) made up the majority (70\%) of snakes recorded, while Midland Painted Turtles (Chrysemys picta marginata) and Snapping Turtles (Chelydra serpentina) accounted for the majority ( $82 \%$ ) of turtles. On average, dead snakes were observed seven times more frequently than dead turtles (Table 3 ).

Just over a fifth (21\%) of all dead snakes and turtles were SAR. Six such species were found in this study: Blanding's Turtle (Emydoidea blandingii), Eastern Musk Turtle (Sternotherus odoratus), Northern Map Turtle (Graptemys geographica), Snapping Turtle, Butler's Gartersnake (Thamnophis butleri), and Eastern Foxsnake (Pantherophis vulpinus). Butler's Gartersnakes, Eastern Foxsnakes, and Snapping Turtles made up the vast majority (92\%) of SAR records. On average, dead SAR snakes were observed twice as often as SAR turtles (Table 3). An additional SAR, the Eastern Massasauga (Sistrurus catenatus catenatus) was found dead opportunistically during the study period (Table 2). Seven provincially listed snakes and turtles were observed dead at the OPC and Greater Park Ecosystem, and, of these, three species appeared to be disproportionately represented.

\section{Temporal and Spatial Patterns of Road Mortality}

Mortality rates differed significantly between months for amphibians $\left(\chi^{2}=1483.12, \mathrm{df}=5, P<0.001\right.$; peak in July-August), birds $\left(\chi^{2}=73.87, \mathrm{df}=5, P<0.001\right.$; peak

TABLE 3. Vertebrate mortality rates recorded during a systematic road mortality survey in the Ojibway Prairie Complex and Greater Park Ecosystem in Windsor and LaSalle, Ontario, from 2010 to 2013. Rates for amphibians, birds, and mammals are based on data from Section B only; rates for all other groups are based on combined data from both sections.

\begin{tabular}{|c|c|c|c|c|c|c|c|c|c|c|c|c|}
\hline \multirow{2}{*}{$\begin{array}{l}\text { Vertebrate } \\
\text { group }\end{array}$} & \multirow{2}{*}{$\begin{array}{c}\text { Average } \\
\text { mortality rate, } \\
\text { no. } / 100 \mathrm{~km}\end{array}$} & \multicolumn{6}{|c|}{$\begin{array}{l}\text { Above average mortality rates by month, } \\
\text { no. } / 100 \mathrm{~km}\end{array}$} & \multicolumn{5}{|c|}{$\begin{array}{l}\text { Above average mortality rates by } \\
\text { road, no. } / 100 \mathrm{~km}^{* \dagger}\end{array}$} \\
\hline & & May & Jun & Jul & Aug & Sep & Oct & Nor & Mal & Mat & Spr & Tod \\
\hline Amphibians & 176.2 & - & - & 607.2 & 192.3 & - & - & & & & & \\
\hline Birds & 24.7 & 32.3 & 48.0 & 40.4 & - & - & - & & & $\mathrm{n} / \mathrm{a}$ & & \\
\hline Mammals & 20.1 & - & 26.9 & 24.4 & 23.0 & - & - & & & & & \\
\hline Snakes & 21.4 & - & - & - & 36.2 & 26.3 & 28.7 & - & 52.3 & - & - & - \\
\hline Turtles & 3.4 & 6.0 & 5.9 & - & - & 4.1 & - & - & - & 7.2 & 4.7 & - \\
\hline \multicolumn{13}{|l|}{ Species at risk } \\
\hline All $\uparrow$ & 5.3 & - & 6.3 & - & 一 & 9.1 & 7.1 & - & 9.4 & 7.4 & - & - \\
\hline Snakes & 3.8 & - & - & - & 一 & 6.6 & 6.3 & 4.0 & 7.0 & 5.3 & - & 3.9 \\
\hline Turtles $\dagger$ & 1.4 & - & 3.2 & - & - & 2.5 & - & - & 2.5 & 2.1 & 1.8 & - \\
\hline
\end{tabular}

*Nor = Normandy Road, Mal = Malden Road, Mat = Matchette Road, Spr = Sprucewood Avenue, Tod = Todd Lane.

Above average mortality rates for snakes, turtles, and species at risk were not observed on Spring Garden or Armanda roads. $\dagger \chi^{2}$ tests were not conducted. 
in May-July), snakes $\left(\chi^{2}=98.5, \mathrm{df}=5, P<0.001\right.$; peak in August-October), SAR snakes $\left(\chi^{2}=32.8, \mathrm{df}=5, P<\right.$ 0.001 ; peak in September-October), and turtles $\left(\chi^{2}=\right.$ 24.71, df $=5, P<0.001$; peaks in May-June and September), but not for mammals $\left(\chi^{2}=6.08, \mathrm{df}=5, P=\right.$ $0.299)$. Temporal patterns remained after controlling for the number of kilometres surveyed per month (Figure 2, Table 3).

Turtle mortality was hatchling-biased in May and September (67\% and $62 \%$, respectively), but not in June (13\%). Over half (62\%) of all dead SAR turtles were found in June and September, whereas most dead non-hatchlings $(70 \%)$ were found in June. Snake mortality was adult-biased (88\%) in August, whereas, in September and October, mortality was more evenly represented by younger age classes (55\% and 67\%, respectively). Over half (65\%) of SAR snake mortality was observed in September and October. Above average mortality rates for SAR turtles and SAR snakes, combined, were observed on Malden and Matchette roads (Table 3 ). The highest diversity of dead snakes and turtles (11 species) and SAR (six species) were observed on Matchette Road. Three SAR (Butler's Gartersnake, Eastern Foxsnake, and Snapping Turtle) were each observed at least once during all months and on most roads.

\section{Road Mortality Hotspots}

Significant aggregations of snake and turtle road mortality events were detected at multiple scales on five of seven roads: Matchette, Malden, Spring Garden, Todd, and Normandy roads (Table 4, Figure 3). Aggregation intensity was highest at the scale of $0.300 \mathrm{~km}$ to $1.050 \mathrm{~km}$ for each of these five roads (Table 4). Significant aggregations were also detected at the scale of $0.050 \mathrm{~km}$ for all five roads except Spring Garden Road. Significant dispersion was detected only on Matchette Road (Table 4, Figure 3).

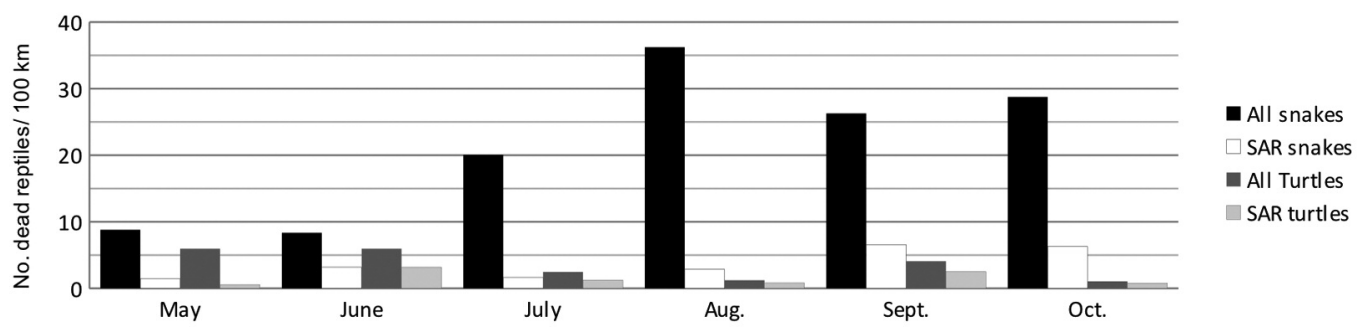

FIgURE 2. Mortality rates recorded during 52 non-consecutive weeks from 2010 to 2013 on seven collector and arterial roads in the Ojibway Prairie Complex and Greater Park Ecosystem in Windsor and LaSalle, Ontario.

TABLE 4. Radii with significant aggregations and dispersions (to the nearest $0.025 \mathrm{~km}$ ) and locations of hotspots (to the nearest $0.050 \mathrm{~km}$ ) determined during a reptile road mortality study in the Ojibway Prairie Complex and Greater Park Ecosystem, Windsor and LaSalle, Ontario, from 2010 to 2013.

\begin{tabular}{|c|c|c|c|c|c|}
\hline \multirow[b]{2}{*}{ Road } & \multirow[b]{2}{*}{$\begin{array}{l}\text { Radii with } \\
\text { significant* } \\
\text { aggregations, } \\
\text { km }\end{array}$} & \multirow[b]{2}{*}{$\begin{array}{l}\text { Radii with } \\
\text { highest } \\
\text { aggregation } \\
\text { intensity, km }\end{array}$} & \multirow[b]{2}{*}{$\begin{array}{l}\text { Radii with } \\
\text { significant* } \\
\text { dispersions, } \\
\text { km }\end{array}$} & \multicolumn{2}{|c|}{$\begin{array}{l}\text { Length (and relative location) of road } \\
\text { mortality hotspots* with greatest intensity, km }\end{array}$} \\
\hline & & & & $\begin{array}{l}\text { Finer scale } \\
(0.050 \mathrm{~km} \\
\text { radii) }\end{array}$ & $\begin{array}{l}\text { Broader } \\
\text { scale } \\
\text { (radii varies) }\end{array}$ \\
\hline Malden Road & $\begin{array}{l}0.025-1.375 \\
1.475-1.550\end{array}$ & $\begin{array}{l}1.050 \\
1.125\end{array}$ & $\mathrm{n} / \mathrm{a}$ & $\begin{array}{l}0.150(\mathrm{~km} \\
0.200-\mathrm{km} 0.350)\end{array}$ & $\begin{array}{l}0.400(\mathrm{~km} 0.000-\mathrm{km} 0.400) \\
0.250 \mathrm{~km} \text { radius }\end{array}$ \\
\hline Matchette Road & $0.025-1.400$ & 0.825 & $1.675-2.725$ & $\begin{array}{l}0.200(\mathrm{~km} 2.750 \\
-\mathrm{km} 2.950)\end{array}$ & $\begin{array}{l}1.000(\mathrm{~km} 2.000-\mathrm{km} \\
3.000) ; 0.825 \mathrm{~km} \text { radius }\end{array}$ \\
\hline Normandy Road & $0.025-1.225$ & 0.850 & $\mathrm{n} / \mathrm{a}$ & $\begin{array}{l}0.300(\mathrm{~km} 0.550 \\
-\mathrm{km} 0.850)\end{array}$ & $\begin{array}{l}0.600(\mathrm{~km} 0.650-\mathrm{km} 1.250) \\
0.450 \mathrm{~km} \text { radius }\end{array}$ \\
\hline Todd Lane & $0.025-0.600$ & 0.300 & $\mathrm{n} / \mathrm{a}$ & $\begin{array}{l}0.200(\mathrm{~km} 0.250 \\
-\mathrm{km} 0.450)\end{array}$ & $\begin{array}{l}0.650(\mathrm{~km} 0.000-\mathrm{km} 0.650) \\
0.300 \mathrm{~km} \text { radius }\end{array}$ \\
\hline Spring Garden Road & $\begin{array}{l}0.225-0.325 \\
0.375-0.400 \\
0.450-0.500\end{array}$ & 0.475 & $\mathrm{n} / \mathrm{a}$ & $\mathrm{n} / \mathrm{a}$ & $\mathrm{n} / \mathrm{a}$ \\
\hline
\end{tabular}

*Based on a $95 \%$ confidence interval. 
A
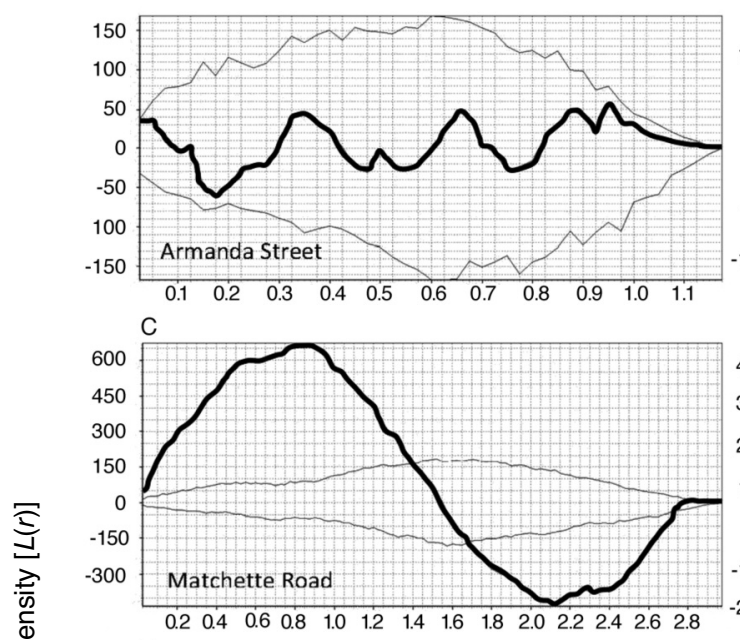
$\mathrm{E}$
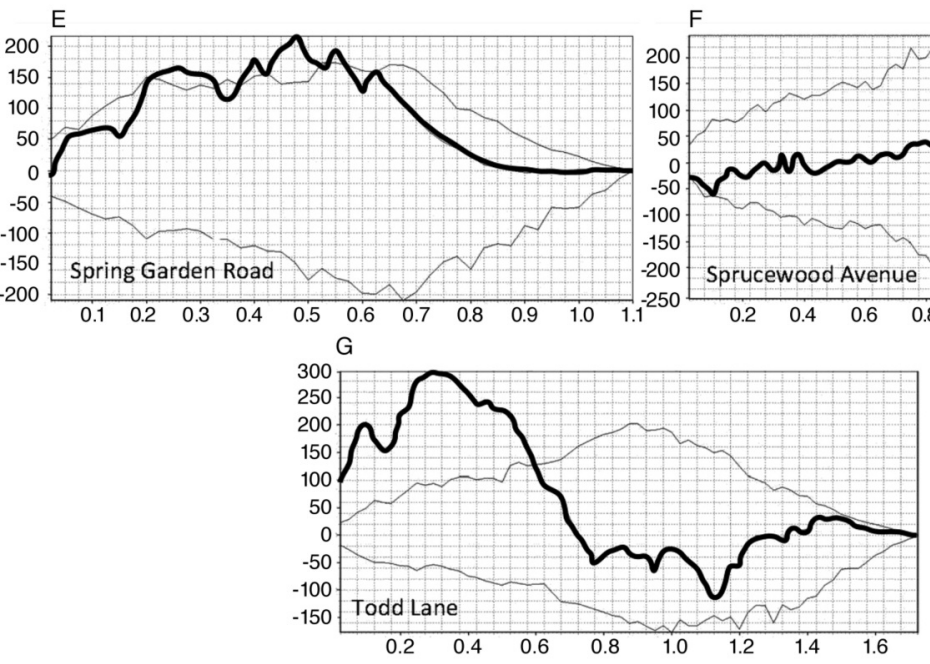

Radius length $(\mathrm{km})$
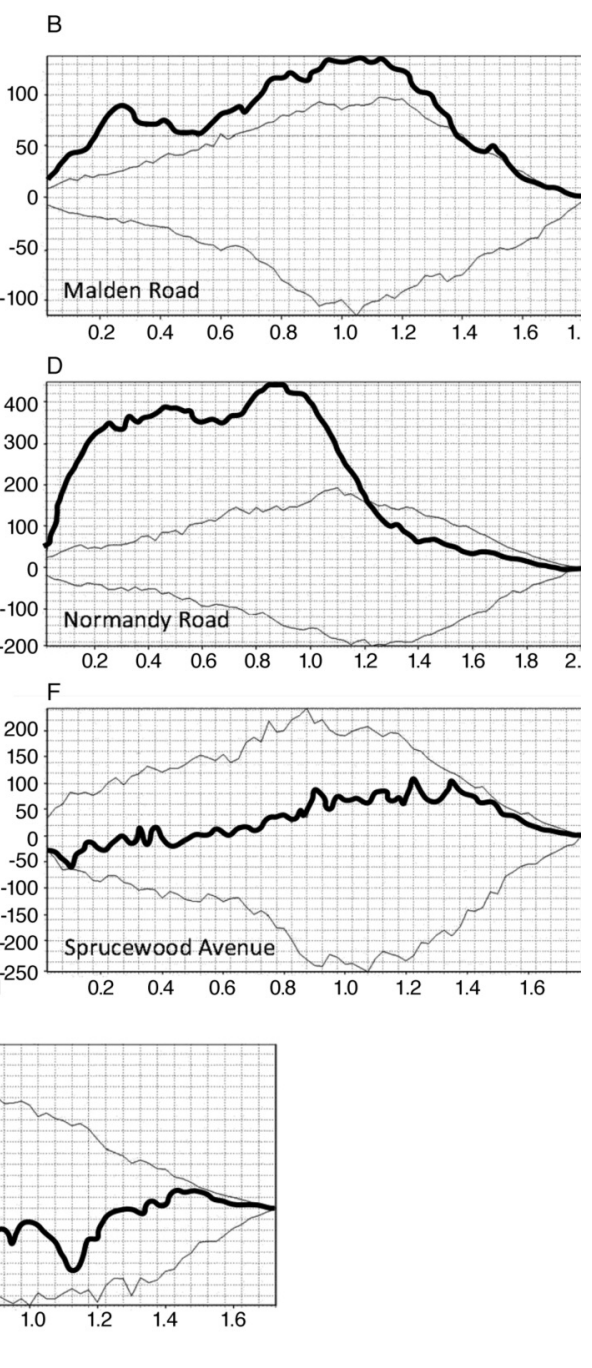
A

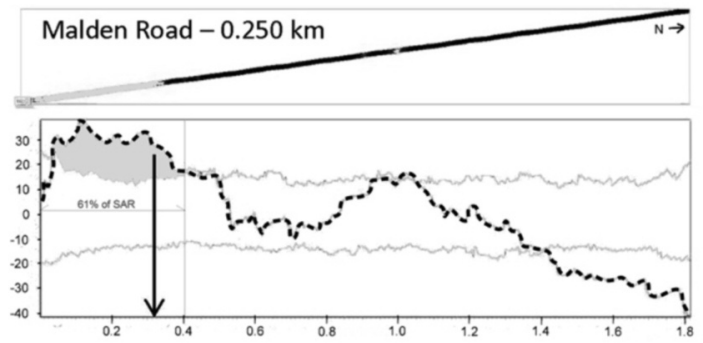

C
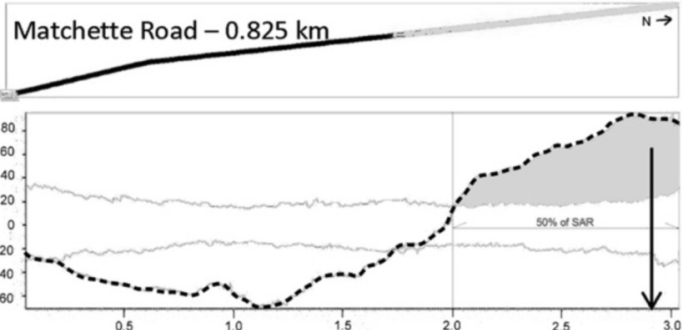

\section{$E$}
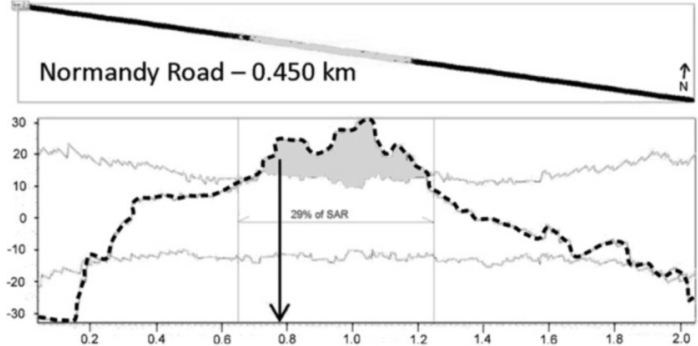

G
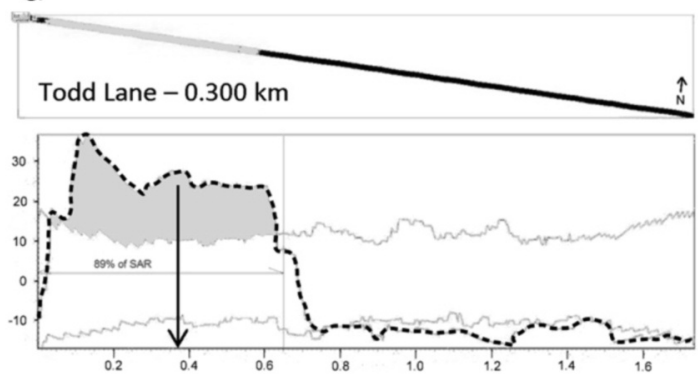

B

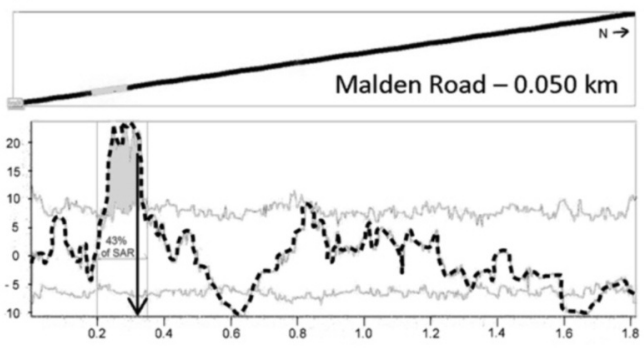

D

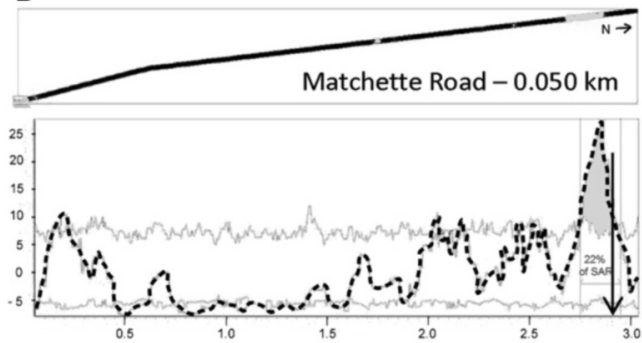

$\mathrm{F}$
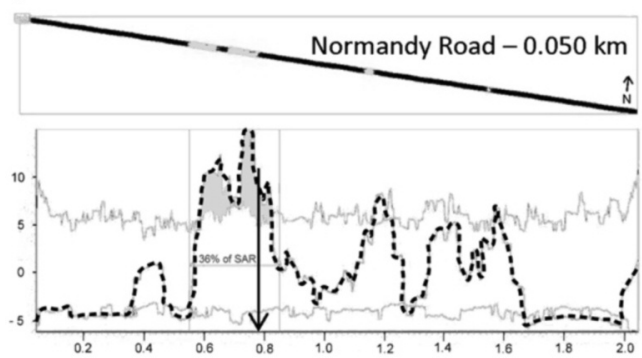

$\mathrm{H}$
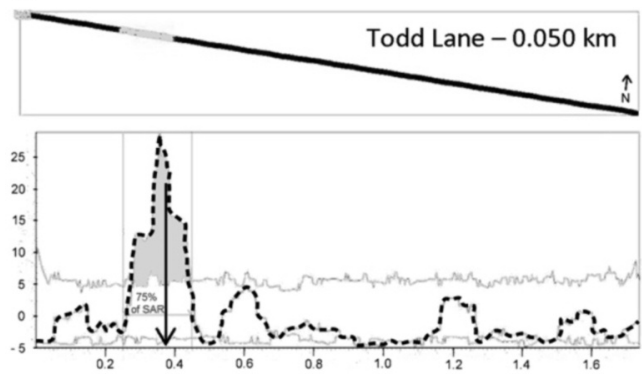

Distance $(\mathrm{km})$ along road from survey start

FIGURE 4. Hotspot analysis for significant spatial aggregations of reptile road mortality events recorded on four roads in the Ojibway Prairie Complex and Greater Park Ecosystem in Windsor and LaSalle, Ontario. In each graph, aggregation intensity $\left(N_{\text {events }}-N_{\text {simulated }}\right)$ is a function of distance $(\mathrm{km})$ along road from survey start (i.e., km 0.0$)$, and $95 \%$ confidence limits are represented by light gray horizontal lines. Significant aggregations of road mortality events (i.e., hotspots) occur where the bold dashed line exceeds the upper confidence limit. Aggregations of greatest intensity are highlighted in light gray, and their approximate extent (to the nearest $0.05 \mathrm{~km}$ ) is indicated by the light gray vertical bars. The proportion of species at risk (SAR) observations that occur within the hotspots (i.e., within the gray bars) is indicated. Above each graph, roads are depicted as a solid black line and segments with significant aggregations of road mortality events are represented in light grey. The scale of analysis (i.e., radii) is indicated next to each road name. Black arrows indicate the approximate location of the utility right-of-way intersection with each road. (Note: for Normandy Road, $50 \%$ of SAR records occured between $\mathrm{km} 0.550$ and $\mathrm{km} \mathrm{1.250)}$ 


\section{Discussion}

Limitations of this Study

We recognize three major limitations to our study: underestimation of the number of species found dead as well as mortality rates; overgeneralization of temporal patterns; and under-representation of spatial aggregations of roadkill.

Ours is not a comprehensive list of all vertebrates killed on roads in and surrounding the OPC. Considering the short time frame of our study, the fact that a large proportion $(41 \%)$ of specimens we collected were not identified to species, and that we only recorded $17 \%$ of the approximately 301 vertebrate species known locally (City of Windsor 2013), it is likely that additional species are being killed on roads in the study landscape.

There is no doubt that the rates of road mortality that we observed are underestimates of the true mortality rates in the study landscape during our study. There are a number of reasons for this. First, most animals killed on roads are removed or obliterated within a day by scavengers, high traffic volumes, or other forces (Kline and Swann 1998; Clevenger et al. 2001; Hels and Buchwald 2001; Enge and Wood 2002; Smith and Dodd 2003; DeGregorio et al. 2011; Santos et al. 2011; Farmer and Brooks 2012), which could result in road mortality being underestimated by a factor of 12-16 (scavenging: Slater 2002, as cited by DeGregorio et al. 2011). Second, surveying by bicycle led to slight underestimates of mortality rates of small snakes compared with surveying on foot (S. Boyle, personal communication, 2013). Third, we did not survey for carcasses in roadside swales, where some animals killed on roads likely ended up (e.g., Dodd et al. 2004). Fourth, we did not estimate or correct for differences in detection rates between observers (i.e., observer bias). Finally, we surveyed only the arterial and collector roads in the study area, not the multiple "local" roads, on which Eastern Foxsnakes have been confirmed killed in 2010, 2012, and 2013 (P. Pratt, unpublished data).

The temporal patterns in road mortality that we observed after pooling data from all three survey years may not be representative of within-year patterns. However, more in-depth analyses of the data are hindered by unequal survey effort within years and, in 2013, a series of temporary road closures on our study roads. Regardless, the patterns we observed for snakes and turtles are consistent with the biology of these two faunal groups. For example, high mortality of turtles in May and June can be explained by adult dispersal during nesting and emergence of hatchlings that overwintered. Also, high mortality of turtles and snakes from August to October can be explained by emergence of neonates as well as snake dispersal to hibernation sites.

Additional aggregations of road mortality may remain undetected in the study landscape because of scavenging pressure, low sample size, or short length of study. Some hotspots could be "masked" if scav- enging pressure is relatively high in those areas. After placing fresh snake carcasses, DeGregorio et al. (2011) found they were removed more often in certain habitat types (forested versus dune habitats). Also, Santos et al. (2011) found that lower traffic rates facilitate scavenger access to carcasses. Although scavengers are present in the study landscape (see Table 2), we did not conduct tests to determine how scavenging pressure is distributed along our study roads. Hotspots were not identified on three roads - Sprucewood, Armanda, and Spring Garden roads - likely because of low sample sizes. Furthermore, our analysis was conducted using data from only two full May-October periods, which might not be sufficient to identify all hotspots. Additional spatial aggregations may become apparent with a larger dataset that spans a longer time.

\section{Impacts of Roads on Ojibway Prairie Vertebrates}

Roads are a conspicuous cause of anthropogenic mortality of vertebrates, especially snakes and species at risk, in the OPC and Greater Park Ecosystem. The average snake road mortality rate of $0.21 / \mathrm{km} /$ day (assuming [384 DOR snakes] / [11.5 km per survey, on average] / [157 surveys]) is higher than those reported at other Ontario sites: $0.06 / \mathrm{km} /$ day at the Long Point Causeway, Port Rowan (Ashley and Robinson 1996), $0.15 / \mathrm{km} /$ day at Rondeau Provincial Park and Point Pelee National Park combined (Farmer and Brooks 2012), and $0.19 / \mathrm{km} /$ day at Dyer's Bay, Northern Bruce Peninsula (Reed and Mackenzie 2010).

We confirmed that seven reptile SAR are being subjected to road mortality at the OPC and Greater Park Ecosystem, and that mortality occurs on all major, and some local, roads in the focal area. During our study, we estimate that SAR were being killed on roads across the OPC at a minimum average rate of 19 individuals a month (assuming: [5.3 DOR/100 km surveyed] $\times$ $[11.5 \mathrm{~km}$ surveyed $/$ survey day, on average $]=[0.61$ $\mathrm{DOR} / \mathrm{day}] \times[30.7$ days/month]). The population-level impacts of the rates of road mortality experienced by SAR in general, and each species in particular, remain unknown. Regardless, road mortality undoubtedly places additional pressure on small populations of reptiles already experiencing a wide range of threats and stressors as a result of inhabiting an urban landscape (Mitchell et al. 2008). Furthermore, management documents for at least two of these species highlight the need to address road mortality and habitat fragmentation across their range (Parks Canada Agency 2013; OMNR 2011).

A precedent has already been set for mitigating road mortality at protected areas across Ontario. For example, using today's SAR designations for reptiles (COSEWIC 2015), the diversity of SAR affected by roads at the OPC (seven) is equal to or greater than that observed at Long Point Provincial Park (seven SAR: Ashley and Robinson 1996), Rondeau Provincial Park (seven SAR: Farmer and Brooks 2012), Point Pelee National Park (four SAR: McKay and Brown 2007; 
Farmer and Brooks 2012), and Bruce Peninsula National Park (four SAR: Eco-Kare International 2010; Reed and McKenzie 2010). Efforts to mitigate road mortality are complete or underway in all four of these parks. Our results provide insight into where and when similar mitigation efforts would have the greatest impact in terms of reducing road morality at the OPC and Greater Park Ecosystem.

\section{Management Considerations}

Mitigation measures would produce the greatest benefit for SAR and other reptiles if they are prioritized at locations where SAR road mortality is highest or during periods of peak mortality rates, or both. Our results suggest that the following four roads should be targeted: Malden, Matchette, Normandy, and Todd. At a minimum, the installation of physical mitigation structures (e.g., barrier walls or fencing), 150-300 $\mathrm{m}$ in length, at the intersection of each of these roads and the utility right-of-way, for a total of $850 \mathrm{~m}$, would target road sections where, collectively, over a third of SAR mortality was recorded. If these structures were extended to $400-1000 \mathrm{~m}$, depending on the road, for a total of $2650 \mathrm{~m}$, mitigation measures would target road sections where just over half of all SAR mortality was recorded on these roads. Furthermore, there is an opportunity for mitigation measures along the four roads mentioned above to contribute not only to reducing road mortality, but also to increasing landscape connectivity for snakes and turtles.

The utility right-of-way that bisects the study landscape is managed to prevent development of a forest canopy, thus providing a continuous corridor of suitable open habitat for snakes, particularly in areas dominated by residential development or dense forest. Results from this road mortality study, in combination with previous habitat suitability modeling for Eastern Massasauga (Choquette 2011) and radiotelemetry data on Eastern Foxsnakes (S. Marks, personal communication, 2013), suggest that the right-of-way is either used as a movement corridor or has potential to function as a corridor for SAR snakes in the study area. Considering the importance of protecting and restoring connectivity in this fragmented landscape, mitigation work done on roads in the vicinity of the utility right-of-way should combine efforts to reduce road mortality and increase connectivity (e.g., diverting animals to newly installed, or existing culverts, with the use of barrier fencing).

In addition to permanent solutions, and to address the widespread nature of SAR road mortality, temporary mitigation measures (e.g., seasonal road closures, seasonal speed limit reductions, etc.) could be used during peak mortality periods for certain taxa and age classes, at a minimum, in June, September, and October, when relatively high mortality rates of snake and turtle SAR were observed. Efforts could be further extended to include May and August to cover additional periods of high turtle and snake mortality. Finally, the potential benefits to all vertebrate groups of permanent road closures or traffic speed reductions should not be overlooked (see Martinson 2009; Farmer and Brooks 2012).

\section{Acknowledgements}

We thank R. Brooks, K. Gunsen, and C. McLaren for their comments on earlier versions of this manuscript. Funding for the 2012-2013 portions of this study was provided mainly through the Ministry of Natural Resources' Species at Risk Stewardship Fund. Partial funding in 2012-2013 was also provided by Ojibway Defence (made possible by a Climate Grant and a Project Grant by Freshwater Future). Partial funding for a field technician in 2013 was provided by Carolinian Canada Coalition through their Conservation Internship Program. Funding for previous years was provided by Ojibway Defence (through a grant from Freshwater Future) and the Save Ojibway Group.

B.-A. Jaksic and E. Primeau conducted systematic road mortality surveys in 2012 and 2013, respectively. The Ojibway Nature Centre (ONC) graciously provided a base of operations for the field technician in 2012 and allowed us to gather incidental observation data from their wildlife sightings book. Wildlife Preservation Canada provided important administrative assistance and support to the lead author and field technicians from 2013 to 2015.

Other opportunistic records from the study landscape were obtained from naturalists and citizen scientists (K. Fawdry, R. Jones, S. Marks, A. L. Meloche, M. Montsch, N. Pancheshan, T. Preney, and J. Row). Thanks to the following organizations for providing opportunistic records or allowing us to search their databases: Ministry of Natural Resources and Forestry (Aylmer), Natural Heritage Information Centre/Ontario Herpetofaunal Summary, Windsor/Essex County Humane Society, and Wings Wildlife Rehabilitation Centre. ONC employees, S. Marks and R. Jones, provided assistance identifying unknown vertebrates from digital photos. The Essex Region Conservation Authority provided boundaries for Candidate Natural Heritage Sites in the study landscape and the City of Windsor Planning Department provided boundaries of the Ojibway Prairie Complex. Thank you to P. Bouliane (transportation planner, City of Windsor), S. Boyle (graduate student, Lakehead University) and S. Marks (species at risk reptile specialist, Amec Foster Wheeler) for sharing relevant information.

\section{Literature Cited}

Aresco, M. J. 2005. Mitigation measures to reduce highway mortality of turtles and other herpetofauna at a north Florida lake. Journal of Wildlife Management 69: 549-560.

Ashley, E. P., and J. T. Robinson. 1996. Road mortality of amphibians, reptiles and other wildlife on the Long Point Causeway, Lake Erie, Ontario. Canadian Field-Naturalist 110: 403-412. 
Baxter-Gilbert, J. H., J. L. Riley, D. Lesbarrères, and J. D. Litzgus. 2015. Mitigating reptile road mortality: fence failures compromise ecopassage effectiveness. PLoS ONE 10: e0120537.

Choquette, J. D. 2011. Reconnecting rattlers: identifying potential connectivity for an urban population of Eastern Massasauga Rattlesnakes. MLA dissertation, University of Guelph, Guelph, Ontario, Canada.

City of Windsor. 2007. City of Windsor Official Plan. Volumes 1 and 2. City of Windsor, Windsor, Ontario, Canada.

City of Windsor. 2013. Ojibway Nature Centre. City of Windsor, Windsor, Ontario, Canada. Accessed January 2014. http://www.ojibway.ca/index.htm.

Clevenger, A. P., M. McIvor, D. McIvor, B. Chruszcz, and K. Gunson. 2001. Tiger Salamander, Ambystoma tigrinum, movements and mortality on the Trans-Canada Highway in southwestern Alberta. Canadian Field-Naturalist 115: 199-204.

Coelho, A. V. P., I. P. Coelho, and A. Kindel. 2006. SIRIEMA: Spatial Evaluation of Road Mortality Software. User's Guide V.1.1. Unversidade Federal do Rio Grande do Sul, Porto Alegre, Brazil.

Coelho, I. P., A. Kindel, and A. V. P. Coelho. 2008. Roadkills of vertebrate species on two highways through the Atlantic Forest Biosphere Reserve, southern Brazil. European Journal of Wildlife Research 54: 689-699.

COSEWIC (Committee on the Status of Endangered Wildlife in Canada). 2015. Canadian wildlife species at risk. Canadian Wildlife Service, Environment Canada, Ottawa, Ontario, Canada. Accessed 21 February 2016. http: //www.cosewic.gc.ca/eng/sct0/rpt/csar_fall_2015_e.pdf.

County of Essex. 2014. County of Essex Interactive Mapping. Accessed 19 January 2015. http://maps.countyofessex.ca.

Crother, B. I. 2012. Scientific and Standard English Names of Amphibians and Reptiles of North America North of Mexico, with Comments Regarding Confidence in our Understanding. 7th edition. Herpetological circular 39. Society for the Study of Amphibians and Reptiles, Shoreview, Minnesota, USA.

DeGregorio, B. A., T. E. Hancock, D. J. Kurz, and S. Yue. 2011. How quickly are dead road-killed snakes scavenged? Implications for underestimates of road mortality. Journal of the North Carolina Academy of Science 127: 184-188.

Dillon Consulting. 2007. LaSalle road needs study 2006. Prepared for the Town of LaSalle (project no. 06-6357-1001). Dillon Consulting, Windsor, Ontario, Canada.

Dillon Consulting. 2009. Corporation of the Town of LaSalle Bridge Needs Study 2008. Prepared for the Town of LaSalle (project no. 08-9481-1000). Dillon Consulting, Windsor, Ontario, Canada.

Dodd, Jr., C. K., W. J. Barichivich, and L. L. Smith. 2004. Effectiveness of a barrier wall and culverts in reducing wildlife mortality on a heavily traveled highway in Florida. Biological Conservation 118: 619-631.

Eco-Kare International. 2010. Cyprus Lake road pre-mitigation assessment. Final report to Bruce Peninsula National Park. Eco-Kare International, Peterborough, Ontario, Canada.

Enge, K. M., and K. N. Wood. 2002. A pedestrian road survey of an upland snake community in Florida. Southeastern Naturalist 1: 365-380.

Farmer, R. G., and R. J. Brooks. 2012. Integrated risk factors for vertebrate roadkill in southern Ontario. Journal of Wildlife Management 76: 1215-1224.
Hels, T., and E., Buchwald. 2001. The effect of road kills on amphibian populations. Biological Conservation 99: 331340 .

Johnson, L. 2005. Carolinian Canada signature sites: a guide to 38 special natural areas in Ontario's deep south and heritage plaques celebrating community conservation. Carolinian Canada Coalition, London, Ontario, Canada.

Kline, N. C., and D. E., Swann. 1998. Quantifying wildlife road mortality in Saguaro National Park. Pages 23-31 in Proceedings of the International Conference on Wildlife Ecology and Transportation. Edited by G. L. Evink, P. Garrett, D. Zeigler, and J. Berry. Florida Department of Transportation, Tallahassee, Florida, USA.

Langen, T. A., A. Machniak, E. K. Crowe, C. Mangan, D. F. Marker, N. Liddle, and B. Roden. 2007. Methodologies for surveying herpetofauna mortality on rural highways. The Journal of Wildlife Management 71, 1361-1368.

Martinson, A. J. 2009. Modeling road mortality of Prairie Rattlesnakes and Bullsnakes in Alberta. M.Ed. thesis, University of Calgary, Calgary, Alberta, Canada.

McKay, V., and H. Brown. 2007. Point Pelee National Park of Canada: wildlife road mortality response. Roads and Ecopassages Forum, 20-22 March 2007, Toronto, Ontario, Canada.

Mitchell, J. C., R. E. Jung Brown, and B. Bartholomew. 2008. Urban Herpetology. Society for the Study of Amphibians \& Reptiles.

OMNR (Ontario Ministry of Natural Resources). 2011. Eastern Foxsnake - Carolinian and Georgian Bay populations. Ontario government response statement. Ontario Ministry of Natural Resources, Peterborough, Ontario, Canada.

Parks Canada Agency. 2013. Recovery Strategy for the Massasauga (Sistrurus catenatus) in Canada. Species at Risk Act recovery strategy series. Parks Canada, Ottawa, Ontario, Canada.

Reed, G., and T. McKenzie. 2010. Dyer's Bay, northern Bruce Peninsula, snake roadkill study 2009. Accessed February 2016. http://bpbo.ca/other-reports/dyers-bay-snakeroad-kill-study/.

Rodger, L. 1998. Tallgrass communities of Southern Ontario: a recovery plan. World Wildlife Fund and the Ontario Ministry of Natural Resources, Toronto, Ontario, Canada.

Row, J. R., G. Blouin-Demers, and P. J. Weatherhead. 2007. Demographic effects of road mortality in black ratsnakes (Elaphe obsoleta). Biological Conservation 137: 117-124.

Santos, S. M., F. Carvalho, and M. Antonio. 2011. How long do the dead survive on the road? Carcass persistence probability and implications for road-kill monitoring surveys. PLoS ONE 6: 1-12.

Shepard, D. B., M. J. Dreslik, B. C. Jellen, and C. A. Phillips. 2008. Reptile road mortality around an oasis in the Illinois corn desert with emphasis on the endangered Eastern Massasauga. Copeia 2008: 350-359.

Smith, L., and C. K. Dodd, Jr. 2003. Wildlife mortality on U.S. highway 441 across Paynes Prairie, Alachua County, Florida. Florida Scientist 66: 128-140.

Town of LaSalle. 2014. Town of LaSalle Zoning By-Law. Schedule C. Town Council, LaSalle, Ontario, Canada.

Vijayakumar, S. P., K. Vasudevan, and N. M. Ishwar. 2001. Herpetofaunal mortality on roads in the Anamalai Hills, southern Western Ghats. Hamadryad (Madras) 26: 253260.

Received 20 April 2015

Accepted 3 December 2015 